\title{
Biodegradation Potentials of Cassava Mill Effluent (CME) by Indigenous Microorganisms
}

\author{
${ }^{* 1}$ ENERIJIOFI, KE; ${ }^{2}$ EKHAISE, FO; ${ }^{1}$ EKOMABASI, IE \\ ${ }^{l}$ Department of Biological Sciences, College of Basic and Applied Sciences, Samuel Adegboyega University, Km 1, Ogwa - Ehor Road, \\ P. M. B. 001, Ogwa, Edo State. \\ ${ }^{2}$ Department of Microbiology, Faculty of Life Science, University of Benin, Benin City \\ ${ }^{1 x}$ Corresponding author: kingsmorelluv@gmail.com; kenerijiofi@ sau.edu.ng; 08034553580.
}

\begin{abstract}
The indiscriminate discharge of Cassava mill effluent pose serious environmental and public health implications. This work was aimed at assessing the biodegradation potentials of indigenous microbial isolates from cassava mill effluent using screening and shake flask degradation tests. The mean heterotrophic bacterial and fungal counts were $3.4 \pm 0.26 \times 10^{6} \mathrm{cfu} / \mathrm{ml}$ and $1.1 \pm 0.20 \times 10^{6} \mathrm{cfu} / \mathrm{ml}$ respectively. The microorganisms isolated, characterized and identified include the genus Pseudomonas (15.48\%), Bacillus (12.41\%), Acetobacter and Rhizopus (10.88\%), Corynebacterium (9.33\%), Lactobacillus, Micrococcus and Aspergillus (7.79\%), Staphylococcus and Penicillium $(6.25 \%)$ and Saccharomyces species (4.62\%). The $\mathrm{pH}(5.39 \pm 0.14)$, electrical conductivity (2506.90 \pm 45.35$)$, sulphate $(210.87 \pm 5.31)$, nitrate $(365.28 \pm 3.61)$, phosphate $(107.70 \pm 2.10)$, cyanide $(19.93 \pm 0.25)$, chemical oxygen demand (1728.33 \pm 19.66$)$, biological oxygen demand $(1141.51 \pm 12.69)$, iron (206.43 \pm 2.05$)$, zinc $(54.56 \pm 0.62)$, manganese (19.96 \pm 0.35$)$, copper $(10.67 \pm 0.10)$ and nickel $(3.28 \pm 0.46)$ in $\mathrm{mg} / \mathrm{l}$ were above the Federal Environmental Protection Agency standard for effluent discharge. Bacillus, Pseudomonas, Aspergillus and Penicillium species which had the highest turbidity were used for bioremediation studies. The consortium of microorganisms demonstrated the highest efficacy. Bioremediation of cassava mill effluent by these microorganisms was manifested in the reduction of biological oxygen demand (consortium of Pseudomonas and Bacillus species 97.42\%), (Aspergillus and Penicillium species 75.32\%) and chemical oxygen demand (Pseudomonas and Bacillus species 37.63\%), (Aspergillus and Penicillium species $44.97 \%$ ). The study has shown that microbial isolates have the potentials of reducing pollution effect thereby enhancing management of cassava mill effluent before eventual discharge into the environment. @JASEM

https://dx.doi.org/10.4314/jasem.v21i6.5
\end{abstract}

Keywords: Biodegradation, Environmental management, Microorganisms, Turbidity, Cassava mill effluent, Ebelle.

Cassava mill effluents are produced from various stages involved in processing of Cassava tubers like washing, grating and moisture extraction processes. The processing of cassava tubers have been reported to be associated with large discharge of effluents which contains substances that are lethal, mobile in soil, affect biodiversities, cause extinction of benthic macro invertebrates, makes marine lives difficult to survive, inhibit germination of cereal seed and destroy microbes (Eziegbo et al., 2014; Olorunfemi et al., 2008). The increased importance of cassava in agricultural and economic development as well as in food security particularly in Nigeria should give its processing and waste handling more attention. Presently, the methods involved in cassava processing are referred to as crude and unstandardized, lacking scientific principles and waiting for possible upgrade (Okunade and Adekalu, 2013).

Bioremediation entails utilizing microorganisms to clean up contaminants in the environment and some of the microorganisms employed include members of the genera Pseudomonas, Flavobacterium, Azotobacter, Bacillus, Serratia, Aspergillus and Penicillium (Ajuzie et al., 2015; Anoliefo and Ikhajiagbe, 2015; Eziegbo et al., 2014). However, studies on bioremediation of cassava mill effluent are rare making this an eye - opener for more studies in this respect. The potentials of microorganisms to catabolize and metabolize xenobiotic compounds have been recognized as potentially effective means of toxic and hazardous wastes disposal and management. That microorganisms are ubiquitous in nature is a proven fact, so also is the age long fact that microorganisms not only cause diseases in humans or deterioration of substances but also useful in the manufacturing industries and degradation or transformation of both organic and inorganic substances (Ajuzie et al., 2015). In fact, the degradative ability of microorganisms is the reason why we are not all deep in environmental pollution crisis today. In Ebelle, like most Nigerian cities, cassava processing is done mainly at subsistent level and indiscriminate discharge is the other of the day. However, the future may see larger cassava processing plants and waste effluents handling may become a major challenge. This study was carried out to identify indigenous microorganisms present in cassava mill effluent and ascertain their potentials to degrade the effluent.

\section{MATERIALS AND METHODS}


Description of the Studied Area: Ebelle is situated in Igueben Local Government Area of Edo State, with geographical coordinates $6^{\circ} 30^{\prime} 0^{\prime \prime}$ North, $6^{\circ} 12^{\prime} 0^{\prime \prime}$ East. The residents are mainly subsistent farmers with cassava tubers making the greatest chunk of their produce. The samples were collected from Cassava processing mill established by the FADAMA (III) project in 2012. The cassava processing mill is operated by Mr. Philip Osajie, an indigene of the community.

Collection of cassava mill effluent sample: Cassava mill effluents were collected from FADAMA (III) cassava processing mill site at Ebelle, Edo state. A sterile four (4) litre plastic container was used to collect the samples in triplicate. The samples were immediately transported to the laboratory for microbiological and physiochemical analyses within two hours of collection.

Enumeration of total heterotrophic bacterial and fungal counts: Ten - fold serial dilution of the cassava mill effluent sample was prepared. Aliquot $1 \mathrm{ml}$ of appropriate ten - fold serial dilution $\left(10^{-3}, 10^{-6}\right.$ and $\left.10^{-9}\right)$ of the cassava mill effluent sample was inoculated into nutrient and potato dextrose agars plates containing fuscin and streptomycin in triplicate using pour plate method for bacterial and fungal enumeration respectively (Cheesbrough, 2006). The inoculated plates were incubated at $37^{\circ} \mathrm{C}$ for $24 \mathrm{hrs}$ in an incubator and at room temperature of $28^{\circ} \mathrm{C}$ for $72 \mathrm{hrs}$ for the enumeration of the total heterotrophic bacterial and fungal counts respectively. The results were expressed in colony forming units per millilitre of the sample ( $\mathrm{cfu} / \mathrm{ml})$.

Characterization and Identification of bacterial and fungal isolates: Discrete colonies of bacterial and fungal isolates were purified by sub - culturing thrice into freshly prepared nutrient and potato dextrose agars plates respectively. Pure cultures of bacterial isolates were characterized and identified based on their cultural, morphological and biochemical characteristics (Holt et al., 1994) while pure cultures of fungal isolates were identified based on cultural characteristics and microscopically using lactophenol blue (Barnett and Hunter, 1972).

Determination of physicochemical parameters and heavy metals concentrations: The method of APHA, (2011) was used to determine the physicochemical parameters which included $\mathrm{pH}$, electrical conductivity, total dissolved solids, turbidity, alkalinity, chloride, sulphate, nitrate, cyanide, phosphate, chemical oxygen demand, dissolved oxygen and biochemical oxygen demand. The cations $\left(\mathrm{Na}^{+}, \mathrm{K}^{+}, \mathrm{Ca}^{2+}\right.$ and $\left.\mathrm{Mg}^{2+}\right)$ were determined with a flame photometer, model Jenway model PFP7 while the heavy metals concentrations were analysed with the aid of atomic absorption spectrophotometer, model PG 550 (Edori and Edori, 2012).

Screening of microbial isolates for the utilization of cassava mill effluent: The modified methods of (Ajuzie et al., 2015; Shabnam et al., 2014) were used. Bacterial and fungal isolates were screened for their utilization of cassava mill effluent using a Mineral Salt Medium (MSM). The medium was autoclaved at $121^{\circ} \mathrm{C}$ for $15 \mathrm{mins}$. Potassium cyanide (KCN) solution was added to the medium as nitrogen source and glucose $(1 \mathrm{~g} / \mathrm{l})$ was added as the carbon source. The cell suspension of bacterial and fungal isolates were prepared by taking a loop full of each isolate into $2 \mathrm{ml}$ of the modified Mineral Salt Medium. Five millilitres (5mls) of MSM was transferred into test tube and $0.5 \mathrm{ml}$ of the cassava mill effluent was introduced, sterilized and allowed to cool. Two drops of the cell suspension was inoculated into the medium and incubated at room temperature $\left(28^{\circ} \mathrm{C}\right)$ for 8 days. The tubes were checked for turbidity which indicated the utilization of the cassava mill effluent.

Shake Flask Degradation Test: The method of Ajuzie et al., (2015) was used. Microbial isolates that had the highest turbidity after 8 days were selected for this test. The medium for fungal isolate used was the Mineral Salt Medium (MSM). Twenty millilitres $(20 \mathrm{ml})$ of the medium was prepared in a conical flask and $2 \mathrm{mls}$ of the cassava mill effluent was added to it and the mixture was sterilized by autoclaving at $121^{\circ} \mathrm{C}$ for $15 \mathrm{mins}$. Cell suspension of the fungal isolates were prepared by taking loop full of the isolated fungi into $2 \mathrm{mls}$ of MSM. A consortium of fungi was also prepared using the MSM. For the bacterial isolates, MSM was used (for both cell suspensions and medium for the shake flask degradation test). Aliquot $0.2 \mathrm{ml}$ of the inoculum of bacteria and fungi (isolates and consortium) were dispensed into the flask containing sterilized cassava mill effluent and appropriate growth medium. All flasks were incubated at room temperature $\left(28^{\circ} \mathrm{C}\right)$ on a rotary shaker at $120 \mathrm{rpm}$ for 10 days. 
Statistical Analysis: The data were analysed and expressed as Mean \pm standard error of triplicate samples.

\section{RESULTS AND DISCUSSION}

Table 1 revealed the mean total heterotrophic bacterial and fungal counts. The mean heterotrophic bacterial and fungal counts were $3.4 \pm 0.26 \times 10^{6}$ $\mathrm{cfu} / \mathrm{ml}$ and $1.1 \pm 0.20 \times 10^{6} \mathrm{cfu} / \mathrm{ml}$ respectively. The cassava mill effluent had higher counts than the control which points to the obvious that it contained more nutrients which supported microbial growth and proliferation. Hence, higher counts in the cassava mill effluents than the control. This agreed with the findings of Etinosa and Igiehion, (2015) and Ezeigbo, et al. (2014) where they reported that cassava mill effluent contaminated soils had higher bacteria and fungi counts than the control.

Table 1: Enumeration of Microbial count, $\mathrm{n}$ x $10^{6} \mathrm{cfu} / \mathrm{ml}$

\begin{tabular}{lll}
\hline Microbial count & Mean \pm standard error & Control \\
\hline THBC & $3.4 \pm 0.26$ & $0.8 \pm 0.11$ \\
THFC & $1.1 \pm 0.20$ & $0.2 \pm 0.12$ \\
\hline
\end{tabular}

Legend: THBC - Total heterotrophic bacterial count; THFC Total heterotrophic fungal count. Values represent mean \pm standard error of triplicate samples.

Table 2: Bacterial and Fungal isolates identified

\begin{tabular}{lc}
\hline Bacterial genera & Frequency of isolation (\%) \\
\hline Pseudomonas $\mathrm{sp}$. & 15.48 \\
Bacillus sp. & 12.41 \\
Acetobacter $\mathrm{sp}$. & 10.88 \\
Corynebacterium $\mathrm{sp}$. & 9.33 \\
Lactobacillus $\mathrm{sp}$. & 7.79 \\
Micrococcus $\mathrm{sp}$. & 7.79 \\
Staphylococcus $\mathrm{sp}$. & 6.25 \\
Fungal genera & \\
Rhizopus sp. & 10.88 \\
Aspergillus sp. & 7.79 \\
Penicillium $\mathrm{sp}$. & 6.25 \\
Saccharomyces $\mathrm{sp}$. & 4.62 \\
\hline
\end{tabular}

Table 2 revealed the genera of microbial isolates identified. They included Pseudomonas (15.48\%), Bacillus (12.41\%), Acetobacter and Rhizopus (10.88\%), Corynebacterium (9.33\%), Lactobacillus, Micrococcus and Aspergillus (7.79\%), Staphylococcus and Penicillium (6.25\%) and Saccharomyces species (4.62\%). The study documented a diverse range of microbial isolates with Pseudomonas (15.48\%) being the most frequently occurred among the bacterial species while Aspergillus (10.88\%) was the most frequently occurred of all fungal species reported. The preponderance of these isolates could be due to the biodegradable nature of cassava mill effluent.
However, some of the microorganisms reported in this study had earlier been documented by previous researchers Okechi et al., (2012) and Omotioma et al., (2013) where they reported Proteus mirabilis, Proteus vulgaris, Staphylococcus saprophyticus, Bacillus, Klebsiella, Streptococcus, Aspergillus, Penicillium, Mucor and Rhizopus species. These organisms; Bacillus, Klebsiella and Pseudomonas are considered as opportunistic pathogens that can cause wound infections leading to sepsis. The fungal reported particularly Aspergillus sp. is known for aflatoxin production which destroys the liver by inducing fatty acid metamorphosis of its cells (Enerijiofi and Ajuzie, 2012).

Table 3: Physiochemical and Heavy metals analysis

\begin{tabular}{|c|c|c|}
\hline Parameters & $\begin{array}{l}\text { Mean } \pm \text { standard } \\
\text { error. }\end{array}$ & $\begin{array}{c}\text { FEPA Effluent } \\
\text { Guideline } \\
1991(\mathrm{mg} / \mathrm{l}) . \\
\end{array}$ \\
\hline $\mathrm{pH}$ & $5.39 \pm 0.14$ & $6-9$ \\
\hline $\mathrm{EC}(\mathrm{uS} / \mathrm{cm})$ & $2506.90 \pm 45.35$ & 1000 \\
\hline TDS (mg/l) & $1844.62 \pm 31.05$ & 2000 \\
\hline Turbidity (NTU) & $109.62 \pm 2.21$ & 300 \\
\hline Alkalinity (mg/l) & $27.92 \pm 0.27$ & NA \\
\hline $\mathrm{Cl}^{-}(\mathrm{mg} / \mathrm{l})$ & $17.28 \pm 0.25$ & 600 \\
\hline $\mathrm{SO}_{4}{ }^{2-}(\mathrm{mg} / \mathrm{l})$ & $210.87 \pm 5.31$ & 50 \\
\hline $\mathrm{NO}_{3}^{-}(\mathrm{mg} / \mathrm{l})$ & $365.28 \pm 3.61$ & 1.0 \\
\hline $\mathrm{CN}-(\mathrm{mg} / \mathrm{l})$ & $19.93 \pm 0.25$ & 0.2 \\
\hline $\mathrm{PO}_{4}{ }^{3-}(\mathrm{mg} / \mathrm{l})$ & $107.70 \pm 2.10$ & 5.0 \\
\hline COD (mg/l) & $1728.33 \pm 19.66$ & 40 \\
\hline DO (mg/l) & $8.20 \pm 0.17$ & 40 \\
\hline BOD (mg/l) & $1141.51 \pm 12.69$ & 10 \\
\hline $\mathrm{Na}^{+}(\mathrm{mg} / \mathrm{l})$ & $370.18 \pm 9.34$ & 200 \\
\hline $\mathrm{K}^{+}(\mathrm{mg} / \mathrm{l})$ & $576.14 \pm 6.45$ & NA \\
\hline $\mathrm{Ca}^{2+}(\mathrm{mg} / \mathrm{l})$ & $162.36 \pm 2.87$ & 100 \\
\hline $\mathrm{Mg}^{2+}(\mathrm{mg} / \mathrm{l})$ & $243.51 \pm 6.15$ & 100 \\
\hline $\mathrm{Fe}^{3+}(\mathrm{mg} / \mathrm{l})$ & $206.43 \pm 2.05$ & 20 \\
\hline $\mathrm{Zn}^{2+}(\mathrm{mg} / \mathrm{l})$ & $54.56 \pm 0.62$ & 1.0 \\
\hline $\mathrm{Mn}^{2+}(\mathrm{mg} / \mathrm{l})$ & $19.96 \pm 0.35$ & 0.5 \\
\hline $\mathrm{Cu}^{2+}(\mathrm{mg} / \mathrm{l})$ & $10.67 \pm 0.10$ & 1.5 \\
\hline $\mathrm{Ni}^{2+}(\mathrm{mg} / \mathrm{l})$ & $3.28 \pm 0.46$ & 1.0 \\
\hline $\mathrm{Cd}^{2+}(\mathrm{mg} / \mathrm{l})$ & $0.95 \pm 0.03$ & 1.0 \\
\hline $\mathrm{V}^{2+}(\mathrm{mg} / \mathrm{l})$ & $1.52 \pm 0.35$ & NA \\
\hline $\mathrm{Cr}^{6+}(\mathrm{mg} / \mathrm{l})$ & $0.21 \pm 0.19$ & 0.5 \\
\hline $\mathrm{Pb}^{2+}(\mathrm{mg} / \mathrm{l})$ & $0.33 \pm 0.02$ & 0.5 \\
\hline
\end{tabular}

Legend: values represent mean \pm standard error of triplicate samples.NA:=Not Available

The physicochemical parameters shown in Table 3 revealed that the major pollutants of cassava mill effluent were $\mathrm{pH}(5.39 \pm 0.14)$, electrical 
conductivity $(2506.90 \pm 45.35 \mathrm{uS} / \mathrm{cm})$, sulphate $(210.87 \pm 5.31 \mathrm{mg} / \mathrm{l})$, nitrate $(365.28 \pm 3.61 \mathrm{mg} / \mathrm{l})$, phosphate $(107.70 \pm 2.10 \mathrm{mg} / \mathrm{l})$, cyanide $(19.93 \pm$ $0.25 \mathrm{mg} / \mathrm{l})$, chemical oxygen demand (1728.33 \pm $19.66 \mathrm{mg} / \mathrm{l})$, biological oxygen demand (1141.51 \pm $12.69 \mathrm{mg} / \mathrm{l})$, iron $(206.43 \pm 2.05 \mathrm{mg} / \mathrm{l})$, zinc $(54.56 \pm$ $0.62 \mathrm{mg} / \mathrm{l})$, manganese $(19.96 \pm 0.35 \mathrm{mg} / \mathrm{l})$, copper $(10.67 \pm 0.10 \mathrm{mg} / \mathrm{l})$ and nickel $(3.28 \pm 0.46 \mathrm{mg} / \mathrm{l})$. The aforementioned parameters were above FEPA, (1991) recommended standard limit for effluent discharge. The $\mathrm{pH}$ reported was acidic and it could be due to the high cyanide content reported from the cassava mill effluent. The high electrical conductivity reported could be due to the fact that cassava tubers are rich in anions as corroborated by Etinosa and Igiehion, (2015). Although, the concentration of total dissolved solid reported was less than the FEPA, (1991) effluent limit, it was considerably high which could be attributed to the high solid content of the cassava mill effluent. The degradation of the high total dissolved solid components of cassava mill effluent which required some oxygen for oxidation it's could have resulted in the low dissolved oxygen and high biological oxygen demand reported in this study as earlier reported by Ebukiba, (2010). The high concentration of phosphate, sulphate and nitrate may be because they are components of cassava tubers. The heavy metals were in the abundance ratio; $\mathrm{Fe}>\mathrm{Zn}>\mathrm{Mn}>\mathrm{Cu}>\mathrm{Ni}>\mathrm{V}>\mathrm{Cd}>\mathrm{Pb}>\mathrm{Cr}$. However, the high concentrations reported for heavy metals in the study indicated that the cassava mill effluent is a source of some the heavy metals. Studies of heavy metals in various Nigerian crude oils have shown them to contain relatively high concentrations of $\mathrm{Fe}, \mathrm{Cu}, \mathrm{Zn}, \mathrm{Pb}$ and $\mathrm{Hg}$. Therefore the presence of $\mathrm{Fe}, \mathrm{Cu}, \mathrm{Mn}$ and $\mathrm{Zn}$ in this study could be attributed to the wearing or abrasion farming implement used in harvesting, peeling, cassava milling machine metal parts and emission of these metals through the exhaust of the machine.

Table 4: Turbidity values of indigenous microbial isolates

\begin{tabular}{lccl}
\multicolumn{4}{c}{ Table 4: Turbidity values of indigenous microbial isolates } \\
\hline 1.5x10 ${ }^{6}$ cell suspension & $\begin{array}{l}\text { Day zero } \\
\text { Mean } \pm \text { standard error. }\end{array}$ & $\begin{array}{l}\text { Day four (4) } \\
\text { Mean } \pm \text { standard error. }\end{array}$ & $\begin{array}{l}\text { Day eight }(8) \\
\text { Mean } \pm \text { standard error. }\end{array}$ \\
\hline & & Bacterial isolates \\
Lactobacillus sp. & $1.48 \pm 0.02$ & $9.94 \pm 0.07$ & $8.63 \pm 0.18$ \\
Acetobacter sp. & $1.51 \pm 0.03$ & $12.48 \pm 0.21$ & $11.29 \pm 0.45$ \\
Bacillus sp. & $1.50 \pm 0.02$ & $14.84 \pm 0.23$ & $13.52 \pm 0.29$ \\
Micrococcus sp. & $1.41 \pm 0.03$ & $11.16 \pm 0.12$ & $9.93 \pm 0.15$ \\
Pseudomonas sp. & $1.50 \pm 0.05$ & $20.45 \pm 0.31$. & $19.40 \pm 0.78$ \\
Corynebacterium sp. & $1.48 \pm 0.02$ & $13.53 \pm 0.23$ & $12.33 \pm 0.37$ \\
Staphylococcus sp. & $1.48 \pm 0.04$ & $10.63 \pm 0.09$ & $9.34 \pm 0.45$ \\
Control & $1.49 \pm 0.04$ & $1.48 \pm 0.03$ & $1.53 \pm 0.03$ \\
& & Fungal isolates & \\
Aspergillus sp. & $2.77 \pm 0.05$ & $7.29 \pm 0.15$ & $12.70 \pm 0.25$ \\
Penicillium sp. & $4.61 \pm 0.17$ & $9.42 \pm 0.13$ & $12.43 \pm 0.44$ \\
Control & $2.47 \pm 0.26$ & $2.28 \pm 0.13$ & $2.47 \pm 0.32$ \\
\hline
\end{tabular}

Table 5: $\mathrm{BOD}_{5}$ and $\mathrm{COD}_{5}$ values of cassava mill effluent with bacterial and fungal over a 10-day period at 2days interval (mg/l)

\begin{tabular}{|c|c|c|c|c|c|c|c|}
\hline & 0 & 2 & 4 & 6 & 8 & 10 & $\begin{array}{l}(\%) \mathrm{BOD} \\
\text { reduction }\end{array}$ \\
\hline \multicolumn{8}{|l|}{ Bacterial isolates } \\
\hline Pseudomonas $\mathrm{sp}$. & 197.45 & 98.67 & 86.37 & 42.05 & 28.37 & 17.37 & 91.20 \\
\hline Bacillus sp. & 173.97 & 112.07 & 87.82 & 48.11 & 30.82 & 19.82 & 88.61 \\
\hline Pseudomonas and Bacillus & 170.45 & 97.05 & 67.05 & 33.07 & 12.74 & 4.39 & 97.42 \\
\hline Control & 7.64 & 7.11 & 126.65 & 3.07 & 2.73 & 2.73 & \\
\hline \multicolumn{8}{|l|}{ Fungal isolates } \\
\hline Aspergillus sp. & 99.65 & 88.69 & 60.97 & 52.81 & 32.71 & 28.71 & 71.20 \\
\hline Penicillium sp. & 91.18 & 81.71 & 67.84 & 51.90 & 34.23 & 28.23 & 69.04 \\
\hline $\begin{array}{l}\text { Aspergillus and } \\
\text { Penicillium }\end{array}$ & 87.90 & 78.23 & 54.45 & 45.25 & 38.69 & 21.69 & 75.32 \\
\hline \multirow{2}{*}{$\begin{array}{l}\text { Penicillium } \\
\text { Control }\end{array}$} & 7.64 & 7.11 & 126.65 & 3.07 & 2.73 & 2.73 & \\
\hline & 0 & 2 & 4 & 6 & 8 & 10 & $\begin{array}{l}\% \mathrm{COD} \\
\text { reduction }\end{array}$ \\
\hline
\end{tabular}




\begin{tabular}{|c|c|c|c|c|c|c|c|}
\hline Pseudomonas sp. & 106.16 & 87.23 & 76.76 & 62.99 & 56.06 & 56.06 & 47.19 \\
\hline Bacillus sp. & 108.49 & 88.70 & 78.05 & 65.55 & 58.34 & 58.34 & 46.23 \\
\hline $\begin{array}{l}\text { Pseudomonas and } \\
\text { Bacillus }\end{array}$ & 100.71 & 91.58 & 80.59 & 74.67 & 62.81 & 62.81 & 37.63 \\
\hline $\begin{array}{l}\text { Control } \\
\text { Fungal isolates }\end{array}$ & 109.66 & 106.54 & 106.33 & 153.86 & 136.94 & 136.94 & \\
\hline Aspergillus sp. & 97.85 & 82.53 & 72.63 & 54.80 & 48.77 & 48.77 & 50.16 \\
\hline Penicillium sp. & 110.30 & 79.01 & 69.52 & 66.46 & 59.15 & 59.15 & 46.37 \\
\hline $\begin{array}{l}\text { Aspergillus and } \\
\text { Penicillium }\end{array}$ & 108.49 & 89.58 & 78.83 & 67.08 & 59.70 & 59.70 & 44.97 \\
\hline Control & 109.66 & 106.54 & 106.33 & 153.86 & 136.94 & 136.94 & \\
\hline
\end{tabular}

Bacillus and Pseudomonas species had the high utilizing ability (turbidity) of all the bacterial isolates screened with values $13.52 \pm 0.29$ and $19.40 \pm 0.78$ respectively while Aspergillus and Penicillium species had high utilizing ability of all fungal isolates with values of $12.70 \pm 0.25$ and $12.43 \pm 0.44$ respectively at day 8 (Table 4). The different turbidity values reflected the degree of utilization of cassava mill effluent by these microbial isolates. This implied that the cassava mill effluent contained rich source of biodegradable organic materials which makes it prone to microbial attack and degradation. It also revealed that these microorganisms showed great potentials in utilizing cassava mill effluent as their primary carbon and energy source. However, the presence of these indigenous microorganisms may not a direct indication that they primarily utilize cassava mill effluent as their carbon and energy sources, rather may utilize it as their secondary carbon and energy sources which agreed with the submission of Ajuzie et al., (2015). Table 5 recorded the biodegradation ability of the microbial isolates for biological oxygen demand and chemical oxygen demand. The consortium of Pseudomonas and Bacillus species had the highest percentage reduction (97.42\%) for biological oxygen demand among the consortia while Pseudomonas sp. had the highest percentage reduction (91.20\%) among the individual isolates. Aspergillus and Penicillium species consortium had the highest percentage reduction (44.97\%) for chemical oxygen demand among the consortia while Aspergillus sp. had the highest $(50.16 \%)$ of all the individual isolates. The bacterial isolates were more able to reduce the biological oxygen demand while the fungal isolates were better at reducing chemical oxygen demand in the cassava mill effluent biodegradation studies. The results indicated that microorganisms had the ability to degrade cassava mill effluent with consortium having a greater ability than the individual isolates. However, improved pollutants remediation using bacterial and fungal consortium had previously been reported (Ajuzie et al., 2015; Anoliefo and Ikhajiagbe, 2012).

In conclusion, this study had revealed that cassava mill effluent generally contained high concentrations of physicochemical parameters especially biological oxygen demand and chemical oxygen demand. This study has unveiled the potentials of indigenous microorganisms; Pseudomonas, Bacillus, Aspergillus and Penicillium species to degrade cassava mill effluents when applied in the environmentally friendly clean-up technology (bioremediation) of cassava mill effluent contaminated sites in Ebelle community.

\section{REFERENCES}

Ajuzie, CU; Atuanya, EI; Enerijiofi, KE (2015). Biodegradation potentials of microorganisms isolated from Eleme petrochemical industrial effluent. Nig. Soc. Exper. Biol. J. 5(4):128 -135.

American Public Health Association-APHA (2011). Standard Methods for the examination of Water and Wastewater. American Public Health Association, Washington, D C. p.1193.

Barnett, HL; Hunter, BB (1972). Illustrated Genera of Imperfect Fungi. 3rd edition. Burgess Publishing Company, USA.

Anoliefo, GO; Ikhajiagbe, B (2012). Techniques in bioremediation. In: Okhuoya, JA., Okungbuwa FI and Shittu, HO (eds) Biological Techniques and Application, Uniben Press, Benin City, Nigeria, p. 410.

Cheesebrough, M (2006). District Laboratory Practice in Tropical Countries. Part II, London, Cambridge University Press. P 58-100. 
Ebukiba, E (2010). Economic analysis of cassava production (Farming) in Akwa Ibom State. Agric. Biol. J. Nor. Amer. 1(4):612 - 614.

Edori, OS; Edori, ES (2012). Effect of automechanic works on lead and iron content in two mechanic villages in Portharcourt, Rivers State Nigeria. $J$. Appl. Sci. Environ. Manage. 16 (4):317 - 321.

Enerijiofi, KE; Ajuzie, CU (2012). Health impact of some heavy metals resistance in microbes isolated from Ikhueniro refuse dumpsite, Benin City. Nig. J. Microbiol. 26: 2592 - 2598.

Etinosa, OI; Igiehion, ON (2015). The impact of cassava effluent on the microbial and physiochemical characteristics on soil dynamics and structure. Jor. J. Biol. Sci. 8 (2):107 - 112.

Ezeigbo OR., Ike-Amadi, CA, Okeke, UP; Ekaiko MU (2014). The effect of cassava mill effluent on soil microorganisms in Aba, Nigeria. Int. $J$. Curr. Res. Biosci. Plant Biol. 1(4):21 - 26.

Federal Environmental Protection Agency - FEPA (1991). National Guidelines and Standards for Industrial Effluents, gaseous emissions and hazardous waste Management in Nigeria. Government Press, Lagos.

Holt, GT; Krieg, RN; Sneath, PHA; Staley, TJ; Williams, TS (1994). Manual of Determinative
Bacteriology. $9^{\text {th }}$ edition. Williams and Wilkins Baltimore, USA.

Okechi, RN; Ihejirika, CE; Chiegboka, NA; Chukwura, EI; Ibe, IJ (2012). Evaluation of the effects of cassava mill effluent on the microbial populations and physicochemical parameters at different soil depths. Int. J. Biosci. 2 (12): 139 145.

Okunade, DA; Adekalu, KO (2013). Physicochemical analysis of contaminated water resources due to cassava wastewater effluent disposal. Eur. J. Sci. Technol. 2:75-84.

Olorunfemi, DI; Emoefe, EO; Okieimen, FE (2008). Effect of cassava processing effluent on seedling height, biomass and chlorophyll content of some cereals. Res. J. Environ. Sci. 2:221 - 227.

Omotioma, MI; Mbah, GO; Akpan, IJ; Ibezim, OB (2013). Impact assessment of cassava effluents on Barika Stream in Ibadan, Nigeria. Int. J. Environ. Sci. Manage. Eng. Res. 2 (2): 50 - 56.

Shabnam, M; Soheila, Y; Zahra, GN (2014). Biodegradation of cyanide by a new isolated strain under alkaline conditions and optimization by response surface methodology (RSM). $J$. Environ. Hlth Sci. Eng. 12(85):1 -9. 